

\section{EXPLAINING EXTREME EVENTS OF 20I4 FROM A CLIMATE PERSPECTIVE}

\section{Editors}

Stephanie C. Herring, Martin P. Hoerling, James P. Kossin, Thomas C. Peterson, and Peter A. Stott

Special Supplement to the

Bulletin of the American Meteorological Society

Vol. 96, No. I2, December 2015 
CORRESPONDING EDITOR:

Stephanie C. Herring, PhD

NOAA National Climatic Data Center

325 Broadway, E/CC23, Rm IB-I3I

Boulder, CO, 80305-3328

E-mail: stephanie.herring@noaa.gov

COVER CREDITS:

Front: (CiStockphotos.com/coleong-Winter snow, Boston Massachusetts, United States.

BACK: (CiStockphotos.com/nathanphoto-Legget, CA, United States - August I3 20I4: CAL FIRE helicopter surveys a part of the Lodge Fire, Mendocino County.

\section{HOW TO CITE THIS DOCUMENT}

Citing the complete report:

Herring, S. C., M. P. Hoerling, J. P. Kossin, T. C. Peterson, and P.A. Stott, Eds., 20I5: Explaining Extreme Events of 2014 from a Climate Perspective. Bull.Amer. Meteor. Soc., 96 (I2), SI-SI 72.

Citing a section (example):

Yoon, J. H., S.-Y. S. WANG, R. R. Gillies, L. Hipps, B. KravitZ, and P. J. Rasch, 20I5: Extreme fire season in California: A glimpse into the future? [in "Explaining Extremes of 2014 from a Climate Perspective"]. Bull. Amer. Meteor. Soc., 96 (I2), S5-S9.

\section{EDITORIAL AND PRODUCTION TEAM}

Riddle, Deborah B., Lead Graphics Production, NOAA/NESDIS National Centers for Environmental Information,

Asheville, NC

Love-Brotak, S. Elizabeth, Graphics Support, NOAA/NESDIS National Centers for Environmental Information,

Asheville, NC

Veasey, Sara W., Visual Communications Team Lead, NOAA/ NESDIS National Centers for Environmental Information, Asheville, NC

Griffin, Jessica, Graphics Support, Cooperative Institute for Climate and Satellites-NC, North Carolina State University, Asheville, NC

Maycock, Tom, Editorial Support, Cooperative Institute for Climate and Satellites-NC, North Carolina State University, Asheville, NC
Misch, Deborah J., Graphics Support, LMI Consulting, Inc., NOAA/NESDIS National Centers for Environmental Information, Asheville, NC

Osborne, Susan, Editorial Support, LMI Consulting, Inc., NOAA/NESDIS National Centers for Environmental Information, Asheville, NC

Schreck, Carl, Editorial Support, Cooperative Institute for Climate and Satellites-NC, North Carolina State University, and NOAA/NESDIS National Centers for Environmental Information, Asheville, NC

Sprain, Mara, Editorial Support, LAC Group, NOAA/NESDIS National Centers for Environmental Information, Asheville, NC

Young, Teresa, Graphics Support, STG, Inc., NOAA/NESDIS National Centers for Environmental Information, Asheville, NC 
Abstract.

I. Introduction to Explaining Extreme Events of 2014 from a Climate Perspective .................................

2. Extreme Fire Season in California: A Glimpse Into the Future? …………………..................................

3. How Unusual was the Cold Winter of 2013/14 in the Upper Midwest?............................................10

4. Was the Cold Eastern Us Winter of 2014 Due to Increased Variability? .............................................15

5. The 2014 Extreme Flood on the Southeastern Canadian Prairies .................................................... 20

6. Extreme North America Winter Storm Season of 2013/14: Roles of Radiative Forcing and the Global Warming Hiatus.......................................................................................................................... 25

7. Was the Extreme Storm Season in Winter 2013/14 Over the North Atlantic and the United Kingdom Triggered by Changes in the West Pacific Warm Pool?.

8. Factors Other Than Climate Change, Main Drivers of 2014/15 Water Shortage in Southeast Brazil..

9. Causal Influence of Anthropogenic Forcings on the Argentinian Heat Wave of December 2013

10. Extreme Rainfall in the United Kingdom During Winter 2013/14: The Role of Atmospheric Circulation and Climate Change.

II. Hurricane Gonzalo and its Extratropical Transition to a Strong European Storm.............................5I

12. Extreme Fall 2014 Precipitation in the Cévennes Mountains ........................................................ 56

13. Record Annual Mean Warmth Over Europe, the Northeast Pacific, and the Northwest Atlantic During 2014: Assessment of Anthropogenic Influence.

14. The Contribution of Human-Induced Climate Change to the Drought of 2014 in the Southern

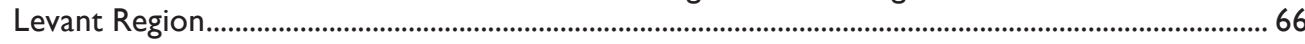

15. Drought in the Middle East and Central-Southwest Asia During Winter 2013/14............................ I

16. Assessing the Contributions of East African and West Pacific Warming to the 2014 Boreal Spring East African Drought

17. The 2014 Drought in the Horn of Africa: Attribution of Meteorological Drivers.

18. The Deadly Himalayan Snowstorm of October 2014: Synoptic Conditions and Associated Trends

19. Anthropogenic Influence on the 2014 Record-Hot Spring in Korea ................................................ 95

20. Human Contribution to the 2014 Record High Sea Surface Temperatures Over the Western Tropical And Northeast Pacific Ocean.

21. The 2014 Hot, Dry Summer in Northeast Asia .............................................................................. 105

22. Role of Anthropogenic Forcing in 2014 Hot Spring in Northern China........................................... III

23. Investigating the Influence of Anthropogenic Forcing and Natural Variability on the 2014 Hawaiian Hurricane Season.

24. Anomalous Tropical Cyclone Activity in the Western North Pacific in August 2014 .................. 120

25. The 2014 Record Dry Spell at Singapore: An Intertropical Convergence Zone (ITCZ) Drought.

26. Trends in High-Daily Precipitation Events in Jakarta and the Flooding of January 2014 ................13।

27. Extreme Rainfall in Early July 2014 in Northland, New Zealand-Was There an Anthropogenic Influence?

28. Increased Likelihood of Brisbane, Australia, G20 Heat Event Due to Anthropogenic Climate Change.

29. The Contribution of Anthropogenic Forcing to the Adelaide and Melbourne, Australia, Heat Waves of January 2014

30 Contributors to the Record High Temperatures Across Australia in Late Spring 2014 ............... 149

3I. Increased Risk of the 2014 Australian May Heatwave Due to Anthropogenic Activity... 154

32. Attribution of Exceptional Mean Sea Level Pressure Anomalies South of Australia in August 2014

33. The 2014 High Record of Antarctic Sea Ice Extent........................................................................ 163

34. Summary and Broader Context........................................................................................................... 168 


\section{ABSTRACT_Stephanie C. Herring, Martin P. Hoerling, James P. Kossin, Thomas C. Peterson, and Peter A. Stott}

Understanding how long-term global change affects the intensity and likelihood of extreme weather events is a frontier science challenge. This fourth edition of explaining extreme events of the previous year (2014) from a climate perspective is the most extensive yet with 33 different research groups exploring the causes of 29 different events that occurred in 2014. A number of this year's studies indicate that human-caused climate change greatly increased the likelihood and intensity for extreme heat waves in 2014 over various regions. For other types of extreme events, such as droughts, heavy rains, and winter storms, a climate change influence was found in some instances and not in others. This year's report also included many different types of extreme events. The tropical cyclones that impacted Hawaii were made more likely due to human-caused climate change. Climate change also decreased the Antarctic sea ice extent in 2014 and increased the strength and likelihood of high sea surface temperatures in both the Atlantic and Pacific Oceans. For western U.S. wildfires, no link to the individual events in 2014 could be detected, but the overall probability of western U.S. wildfires has increased due to human impacts on the climate.
Challenges that attribution assessments face include the often limited observational record and inability of models to reproduce some extreme events well. In general, when attribution assessments fail to find anthropogenic signals this alone does not prove anthropogenic climate change did not influence the event. The failure to find a human fingerprint could be due to insufficient data or poor models and not the absence of anthropogenic effects.

This year researchers also considered other humancaused drivers of extreme events beyond the usual radiative drivers. For example, flooding in the Canadian prairies was found to be more likely because of human land-use changes that affect drainage mechanisms. Similarly, the Jakarta floods may have been compounded by land-use change via urban development and associated land subsidence. These types of mechanical factors reemphasize the various pathways beyond climate change by which human activity can increase regional risk of extreme events. 


\title{
2. EXTREME FIRE SEASON IN CALIFORNIA: A GLIMPSE INTO THE FUTURE?
}

\author{
Jin-Ho Yoon, S.-Y. Simon Wang, Robert R. Gillies, Lawrence Hipps, \\ Ben Kravitz, and Philip J. Rasch
}

The fire season in northern California during 2014 was the second largest in terms of burned areas since 1996. An increase in fire risk in California is attributable to human-induced climate change.

Introduction. California has been under drought conditions since 2012, and the drought worsened considerably in the winter of 2013/14 (e.g., Wang et al. 2014), which fueled an extreme fire season in 2014 (Hart et al. 2015). The early onset of the 2014 dry season (Supplemental Fig. S2.1) fueled an extraordinary jump in wildfires. Between 1 January and 20 September, the California Department of Forestry and Fire Protection reported thousands more fires than the five-year average (www.fire.ca.gov). In early August, a state of emergency was declared for a single wildfire that had burned 32000 acres (http://gov.ca.gov/news .php?id=18645). This unusual fire season is expected to continue well through 2015.

The connection between a warming climate and lengthened fire seasons may seem intuitive, given the general tendency toward a hot-and-dry climate scenario and an earlier snowmelt (Westerling et al. 2006). However, what is not yet fully understood is the extent to which the projected wetter climate in California towards the latter part of the 21st century (Neelin et al. 2013) could affect wildfire risk in the future; this historical drought and unusual fire season also calls attention to possible impacts from humaninduced climate change.

Satellite merged data of burned area from the fourth generation of the Global Fire Emissions Database (GFED4; Giglio et al. 2013) was analyzed (online supplemental material). Because the GFED4 product may underestimate wildfire extent due to its limit in the minimum detectable burned area and obscuration by cloud cover, the Keetch-Byram Drought index

AFFILIATIONS: YoON, KRAVITZ, AND RASCH-Atmospheric Sciences and Global Change Division, Pacific Northwest National Laboratory, Richland, Washington; WANG, GILLIES, AND HIPPSUtah Climate Center/Dept. Plants, Soils and Climate, Utah State University, Logan, Utah

DOI:I0.II75/BAMS-D-I5-00II4.I

A supplement to this article is available online (10.1175 /BAMS-D-I5-001/4.2)
(KBDI; Janis et al. 2002; Keetch and Byram 1968), routinely used by the United States Forest Service for monitoring fire risk, was included as well. The $\mathrm{KBDI}$ is computed with both the observational and simulated daily precipitation and maximum surface temperature. Observational dataset is from the North American Land Data Assimilation phase 2 (NLDAS2; Xia et al. 2012).

Fire extent of 2014. Figure 2.1 shows the annual mean KBDI, the fractional area under extreme fire risk (online supplemental material), and the burned area averaged for entire California (Fig. 2.1a) and northern California-north of $39^{\circ} \mathrm{N}$ (Fig. 2.1b). Both the KBDI and the extreme fire risk exhibit a steady increase over California since 1979 despite the rather large interannual fluctuation. In terms of area burned in GFED4, 2014 ranks the sixth largest in the entire state and second in northern California; but in terms of the KBDI and the extreme fire risk, 2014 ranks first in both the entire state and northern California. Also noteworthy is that the two largest burned areas in northern California, over the 18 -year record of GFED4, occurred in 2012 and 2014. Spatially, the area of higher fire risk in 2014, that is, a KBDI value higher than 400 , extends further north compared to that of 2012 (Figs. 2.1e,f), consistent with the burned area (Figs. 2.1c,d).

Attribution and projection. Wildfire simulations and projections are generally performed using stand-alone vegetation models (e.g., Brown et al. 2004; Cook et al. 2012; Luo et al. 2013; Scholze et al. 2006; Yue et al. 2013) driven by global climate model output. While the advantage of using a stand-alone vegetation model lies in its application to high spatial resolution through downscaling, disadvantages include added uncertainty produced from downscaling (e.g., Shukla and Lettenmaier 2013; Yoon et al. 2012). In this study, 


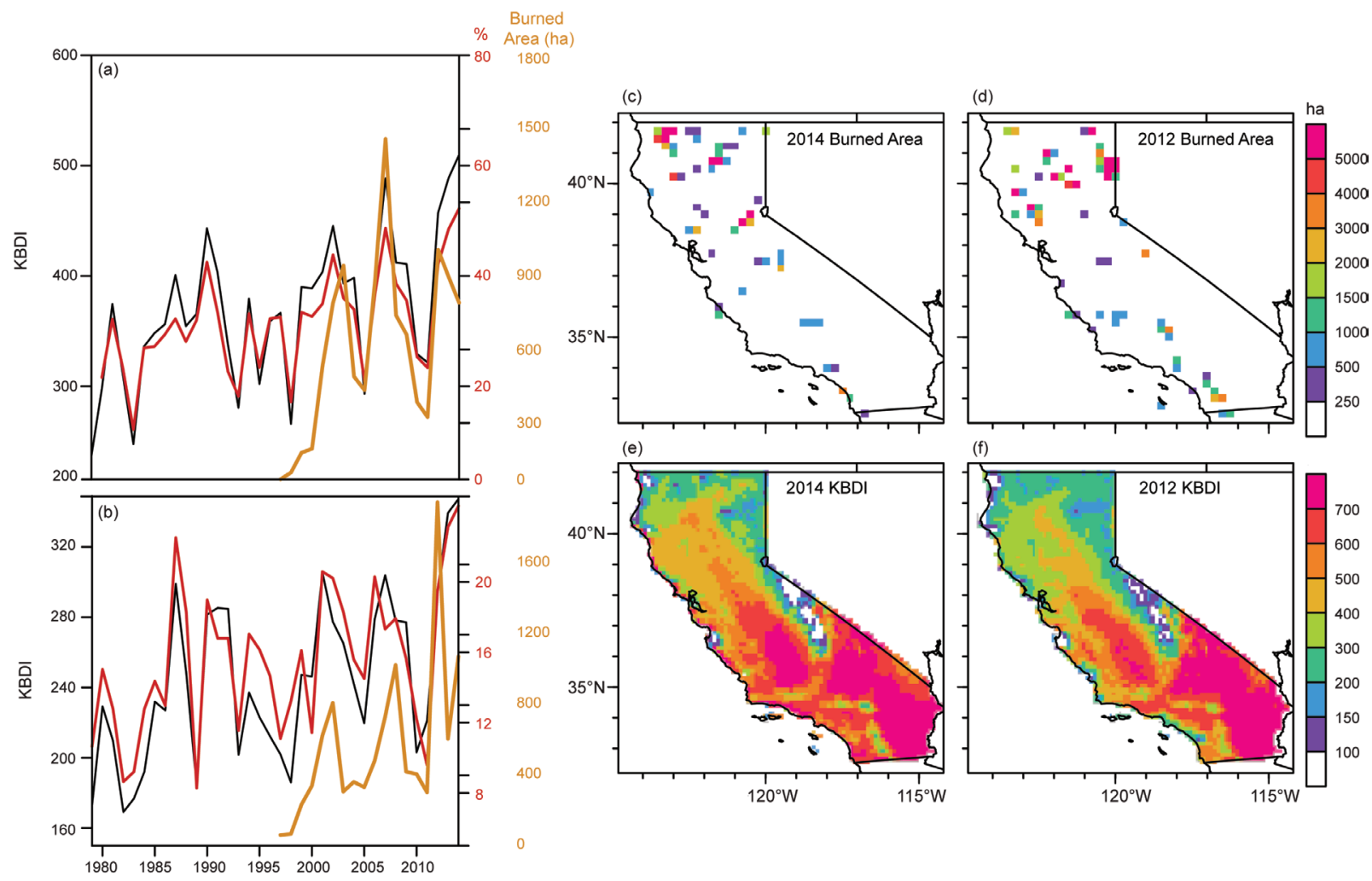

FIG. 2.I. Annual mean of the KBDI in black, fraction of the area that are under the extreme fire risk in red, which is defined as KBDI > 600, and burned area from GFED4 in orange averaged for (a) California and (b) Northern California. Spatial distribution of burned area in hectare (ha) from GFED4 averaged for (c) 2014 and (d) 2012, and corresponding the annual mean KBDI in (e) and (f).

we analyzed both the KBDI and wildfire probabilities computed directly within the Community Earth System Model version 1 (CESM1), which are primarily driven by the dryness of the surface soil and the availability of fuel load, that is, vegetation (Thonicke et al. 2001). Although CESM1's spatial resolution of 1 -degree is relatively coarse, the model does simulate well the climate drivers of fire, such as precipitation and surface air temperature of California (Wang et al. 2014). Further, the CESM1 has produced 30 members (online supplemental material) spanning historical (1920-2005) and future periods (2006-80; based on RCP8.5 scenario), together with a pre-industrial simulation of 1800 years. These model outputs provide a unique opportunity for the detection and attribution study conducted here to assess wildfire probabilities under climate change.

Projections for California did show a steady increase of the fire risk based solely upon the KBDI (Fig. 2.2a) and are consistent with recent studies (Dennison et al. 2014; Lin et al. 2014; Luo et al. 2013; van Mantgem et al. 2013) that indicate increased occurrence of area burned and wildfire intensity and duration over the western United States. The CESM1 projects only a slight increase in annual precipitation accompanied with increasing surface warming after 1990 through 2070 (Supplemental Figs. S2.2b,c), consistent with those produced by the Coupled Model Intercomparison Project Phase 5 (CMIP5) ensembles (Neelin et al. 2013). At face value, these simulations of a slightly wetter climate from 1990 onward could explain the cessation of the simulated fire probability increase at the end of 20th century (Supplemental Fig. S2.2c). However, the KBDI and the extreme fire risk measures, computed here in terms of the fractional area and the extreme fire danger days (Figs. 2.2b,c), do show a steady and rapid increase from early $1990 \mathrm{~s}$ and 2000s.

To what extent can the change of the extreme fire risk over California be attributed to global warming? First, we need to understand how much fluctuation is caused by natural climate variability alone (e.g., Kitzberger et al. 2007). Analyzing the 1800-year pre-industrial simulation of the CESM1 by treating the simulation as 18 member ensembles of 100 -year simulation, the pre-industrial simulations envelops entirely both the KBDI and the extreme fire risk measures fluctuation for the period spanning 1920-80 

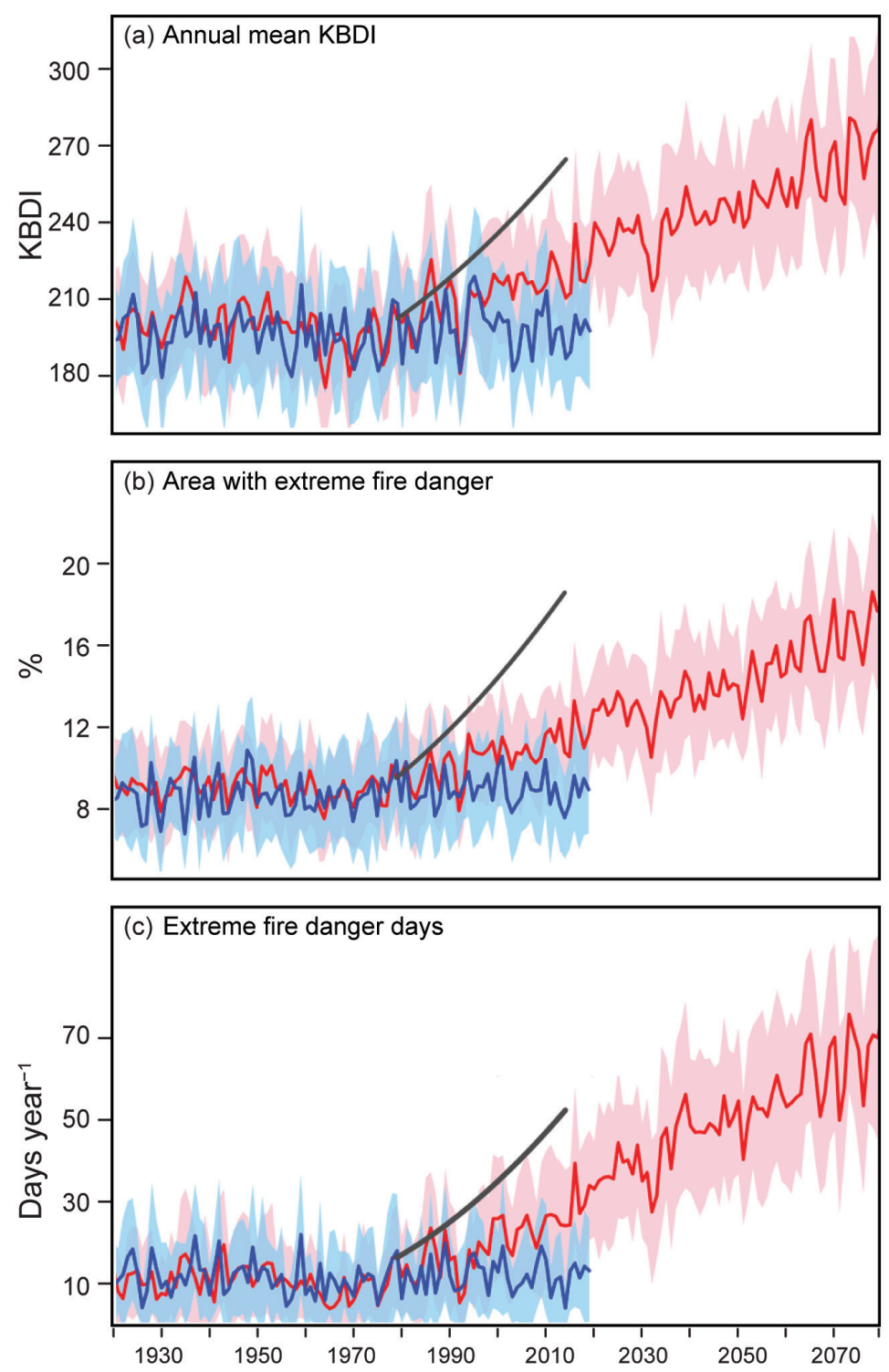

Fig. 2.2. (a) Annual mean of the KBDI from the large ensemble simulation of the CESMI, (b) fractional area (\%) under the extreme fire risk, and (c) the extreme fire danger (days year-l) over California. Red (blue) indicates the historical and RCP8.5 (pre-industrial) runs. Gray lines indicate $50 \%$ of the 2 nd order trend of the KBDI and the extreme fire risk measures based on the NLDAS2. To remove the climatological bias, starting points are adjusted to be the same as the modeled ensemble mean of year 1979.

(Fig. 2.2). Beginning in the 1990s-the later part of the historical simulation-a clear separation emerges between the extreme fire risks driven by the anthropogenic climate forcing and that of natural climate variability. However, 2014 occurred in a period of rapidly increasing extreme fire risk. The pace of increasing extreme fire risk according to simulation has accelerated since the early 21 st century and is expected to surpass the range of natural climate variability. Observations show much faster increases of the KBDI and extreme fire risk measures (gray lines in Fig. 2.2).

The accelerated increase in the KBDI and the extreme fire risk in relation to the projected wetter climate in California is intriguing. To increase extreme fire risk, two basic situations need to be present: one is abundant fuel load (i.e., surface vegetation coverage enhanced through precipitation), and the other is the occurrence of a hot-and-dry climate regime or drought to dry the vegetation. A process called $\mathrm{CO}_{2}$ fertilization (Donohue et al. 2013) tends to increase vegetation activity simply through the uptake of an increasing atmospheric $\mathrm{CO}_{2}$. Under such a scenario along with a wetter climate, vegetation growth would increase and subsequently supply sufficient fuel load. Though population growth and associated urban area change are accounted for in the model, the CESM1 produced fire probability does not account for incidence of human-caused fire ignition, which correlate with population growth.

The extent to which man-made global warming has increased the risk or strength of the recent drought in California has been an active area of research. For example, the severity of the 2014 drought in California was previously analyzed and its potential link to anthropogenic warming was suggested (Diffenbaugh et al. 2015; Wang et al. $2015,2014)$ despite presence of natural climate variability (Wang and Schubert 2014). However, it is important to point out from this study that, the increase in extreme fire risk is expected within the coming decade to exceed that of natural variability and this serves as an indication that anthropogenic climate warming will likely play a significant role in influencing California's fire season.

Conclusions. The 2014 fire season saw the second largest burned area in northern California since 1997, next only to 2012, and ranks the highest since 1979 in the case of extreme fire risk over the entire state. 
Although both fire measures are based upon observations, these derived variables do exhibit uncertainty (Giglio et al. 2013; Xia et al. 2012). The recent extreme fire seasons have occurred in a time of drought. Some measures of extreme fire risk are also expected to increase in the future despite the overall lack of change in the mean fire probability and annual precipitation simulated by climate models for the next 50 years. Our result, based on the CESM1 outputs, indicates that man-made global warming is likely one of the causes that will exacerbate the areal extent and frequency of extreme fire risk, though the influence of internal climate variability on the 2014 and the future fire season is difficult to ascertain.

ACKNOWLEDGEMENTS. Research by Yoon, Kravitz, and Rasch was supported by the Earth System Modeling program in the Office of Science/ DOE and Wang, and Gillies by the WaterSMART grant from the Bureau of Reclamation. Computation was done at the National Energy Research Scientific Computing Center and the Environmental Molecular Sciences Laboratory at PNNL. CESM1 is supported by the NSF and DOE. PNNL is operated for the Department of Energy by Battelle Memorial Institute under Contract DEAC05-76RLO1830.

\section{REFERENCES}

Brown, T., B. Hall, and A. Westerling, 2004: The impact of twenty-first century climate change on wildland fire danger in the western United States: An applications perspective. Climatic Change, 62, 365-388.

Cook, B., N. Zeng, and J.-H. Yoon, 2012: Will Amazonia dry out? Magnitude and causes of change from IPCC climate model projections. Earth Interact., 16, 1-27, doi:10.1175/2011EI398.1.

Dennison, P. E., S. C. Brewer, J. D. Arnold, and M. A. Moritz, 2014: Large wildfire trends in the western United States, 1984-2011. Geophy. Res. Lett., 41, 2928-2933, doi:10.1002/2014GL059576.

Diffenbaugh, N. S., D. L. Swain, and D. Touma, 2015: Anthropogenic warming has increased drought risk in California. Proc. Natl. Acad. Sci. USA, 112, 39313936, doi:10.1073/pnas.1422385112.

Donohue, R. J., M. L. Roderick, T. R. McVicar, and G. D. Farquhar, 2013: Impact of $\mathrm{CO}_{2}$ fertilization on maximum foliage cover across the globe's warm, arid environments. Geophys. Res. Lett., 40, 30313035, doi:10.1002/grl.50563.
Giglio, L., J. T. Randerson, and G. R. van der Werf, 2013: Analysis of daily, monthly, and annual burned area using the fourth-generation global fire emissions database (GFED4). J. Geophys. Res. Biogeosci., 118, 317-328, doi:10.1002/jgrg.20042.

Hart, S. J., T. Schoennagel, T. T. Veblen, and T. B. Chapman, 2015: Area burned in the western United States is unaffected by recent mountain pine beetle outbreaks. Proc. Natl. Acad. Sci. USA, 112, 4375-4380, doi:10.1073/pnas.1424037112.

Janis, M. J., M. B. Johnson, and G. Forthun, 2002: Nearreal time mapping of Keetch-Byram drought index in the south-eastern United States. Int. J. Wildland Fire, 11, 281-289.

Keetch, J. J., and G. M. Byram, 1968: A drought index for forest fire control. U.S.D.A. Forest Service Res. Paper SE-38, 32 pp. [Available online at www.srs .fs.usda.gov/pubs/rp/rp_se038.pdf.]

Kitzberger, T., P. M. Brown, E. K. Heyerdahl, T. W. Swetnam, and T. T. Veblen, 2007: Contingent Pacific-Atlantic Ocean influence on multicentury wildfire synchrony over western North America. Proc. Natl. Acad. Sci. USA, 104, 543-548.

Lin, H.-W., J. L. McCarty, D. Wang, B. M. Rogers, D. C. Morton, G. J. Collatz, Y. Jin, and J. T. Randerson, 2014: Management and climate contributions to satellite-derived active fire trends in the contiguous United States. J. Geophys. Res. Biogeosci., 119, 645660, doi:10.1002/2013JG002382.

Luo, L., Y. Tang, S. Zhong, X. Bian, and W. E. Heilman, 2013: Will future climate favor more erratic wildfires in the western United States? J. Appl. Meteor. Climatol., 52, 2410-2417, doi:10.1175/JAMC-D-12-0317.1.

Mo, K. C., and R. W. Higgins, 1998a: Tropical convection and precipitation regimes in the western United States. J. Climate, 11, 2404-2423.

— and - 1998b: Tropical influences on California precipitation. J. Climate, 11, 412-430.

Neelin, J. D., B. Langenbrunner, J. E. Meyerson, A. Hall, and N. Berg, 2013: California winter precipitation change under global warming in the Coupled Model Intercomparison Project Phase 5 Ensemble. J. Climate, 26, 6238-6256, doi:10.1175 /JCLI-D-12-00514.1.

Scholze, M., W. Knorr, N. W. Arnell, and I. C. Prentice, 2006: A climate-change risk analysis for world ecosystems. Proc. Natl. Acad. Sci. USA, 103, 1311613120. 
Shukla, S., and D. P. Lettenmaier, 2013: Multi-RCM ensemble downscaling of NCEP CFS winter season forecasts: Implications for seasonal hydrologic forecast skill. J. Geophys. Res. Atmos., 118, 10770-10790, doi:10.1002/jgrd.50628.

Thonicke, K., S. Venevsky, S. Sitch, and W. Cramer, 2001: The role of fire disturbance for global vegetation dynamics: Coupling fire into a Dynamic Global Vegetation Model. Global Ecol. Biogeogr., 10, 661677.

van Mantgem, P. J., J. C. B. Nesmith, M. Keifer, E. E. Knapp, A. Flint, and L. Flint, 2013: Climatic stress increases forest fire severity across the western United States. Ecol. Lett., 16, 1151-1156, doi:10.1111 /ele.12151.

Wang, H., and S. Schubert, 2014: Causes of the extreme dry conditions over California during early 2013 [in "Explaining Extreme Events of 2013 from a Climate Perspective”]. Bull. Amer. Meteor. Soc., 95 (9), S7S11.

Wang, S.-Y. S., W.-R. Huang, and J.-H. Yoon, 2015: The North American winter 'dipole' and extremes activity: A CMIP5 assessment. Atmos. Sci. Lett., 16, 338345, doi:10.1002/asl2.565.

— , L. Hipps, R. R. Gillies, and J.-H. Yoon, 2014: Probable causes of the abnormal ridge accompanying the 2013-2014 California drought: ENSO precursor and anthropogenic warming footprint. Geophys. Res. Lett., 41, 3220-3226, doi:10.1002/2014GL059748.

Westerling, A. L., H. G. Hidalgo, D. R. Cayan, and T. W. Swetnam, 2006: Warming and earlier spring increase western US forest wildfire activity. Science, 313, 940-943.

Xia, Y. L., and Coauthors, 2012: Continental-scale water and energy flux analysis and validation for the North American Land Data Assimilation System project phase 2 (NLDAS-2): 1. Intercomparison and application of model products. J. Geophys. Res., 117, D03109, doi:10.1029/2011JD016048.

Yoon, J. H., K. Mo, and E. F. Wood, 2012: Dynamicmodel-based seasonal prediction of meteorological drought over the contiguous United States. J. Hydrometeor., 13, 463-482, doi:10.1175/JHM-D-11-038.1.

Yue, X., L. J. Mickley, J. A. Logan, and J. O. Kaplan, 2013: Ensemble projections of wildfire activity and carbonaceous aerosol concentrations over the western United States in the mid-21st century. Atmos. Environ., 77, 767-780, doi:10.1016 /j.atmosenv.2013.06.003. 


\begin{tabular}{|c|c|c|c|}
\hline \multicolumn{4}{|c|}{ ON EVENT STRENGTH † } \\
\hline & INCREASE & DECREASE & NOT FOUND OR UNCERTAIN \\
\hline Heat & $\begin{array}{l}\text { Australia (Ch. 31) } \\
\text { Europe (Ch.13) } \\
\text { S. Korea (Ch. 19) }\end{array}$ & & $\begin{array}{l}\text { Australia, Adelaide \& Melbourne } \\
\text { (Ch. 29) } \\
\text { Australia, Brisbane (Ch.28) }\end{array}$ \\
\hline Cold & & Upper Midwest (Ch.3) & \\
\hline $\begin{array}{l}\text { Winter } \\
\text { Storms and } \\
\text { Snow }\end{array}$ & & & $\begin{array}{l}\text { Eastern U.S. (Ch. 4) } \\
\text { N. America (Ch. 6) } \\
\text { N. Atlantic (Ch. 7) }\end{array}$ \\
\hline $\begin{array}{c}\text { Heavy } \\
\text { Precipitation }\end{array}$ & Canada** (Ch. 5) & & $\begin{array}{l}\text { Jakarta***** (Ch. 26) } \\
\text { United Kingdom } * * * *(C h .10) \\
\text { New Zealand (Ch. 27) }\end{array}$ \\
\hline Drought & $\begin{array}{l}\text { E. Africa (Ch. 16) } \\
\text { E. Africa* (Ch. 17) } \\
\text { S. Levant (Ch. 14) }\end{array}$ & & $\begin{array}{l}\text { Middle East and S.W. Asia } \\
(\text { Ch. 15) } \\
\text { N.E. Asia (Ch. 2I) } \\
\text { Singapore (Ch. 25) }\end{array}$ \\
\hline $\begin{array}{l}\text { Tropical } \\
\text { Cyclones }\end{array}$ & & & $\begin{array}{l}\text { Gonzalo (Ch. II) } \\
\text { W. Pacific (Ch. 24) }\end{array}$ \\
\hline Wildfires & & & California (Ch. 2) \\
\hline $\begin{array}{l}\text { Sea Surface } \\
\text { Temperature }\end{array}$ & $\begin{array}{l}\text { W. Tropical \& N.E. Pacific (Ch. 20) } \\
\text { N.W. Atlantic \& N.E. Pacific (Ch. 13) }\end{array}$ & & \\
\hline $\begin{array}{l}\text { Sea Level } \\
\text { Pressure }\end{array}$ & S. Australia (Ch. 32) & & \\
\hline $\begin{array}{l}\text { Sea Ice } \\
\text { Extent }\end{array}$ & & & Antarctica (Ch. 33) \\
\hline
\end{tabular}

† Papers that did not investigate strength are not listed.

t† Papers that did not investigate likelihood are not listed.

* No influence on the likelihood of low rainfall, but human influences did result in higher temperatures and increased net incoming radiation at the surface over the region most affected by the drought.

** An increase in spring rainfall as well as extensive artificial pond drainage increased the risk of more frequent severe floods from the enhanced rainfall.

*** Evidence for human influence was found for greater risk of UK extreme rainfall during winter 2013/14 with time scales of 10 days

***** The study of Jakarta rainfall event of 2014 found a statistically significant increase in the probability of such rains over the last 115 years, though the study did not establish a cause. 


\title{
ON EVENT LIKELIHOOD ††
}

Argentina (Ch. 9)

Australia (Ch. 30, Ch. 31)

Australia, Adelaide (Ch. 29)

Australia, Brisbane (Ch. 28)

Melbourne, Australia (Ch. 29)

Europe (Ch. 13)

S. Korea (Ch. 19)

China (Ch. 22)

Cold
Winter
Storms and
Snow

Heavy
Precipitation

(a)

N. America (Ch. 6)

S. France (Ch. 12)

Middle East and S.W. Asia (Ch. 15)

Drought

E. Africa (Ch. 16)

S. Levant (Ch. 14)

E. Africa* (Ch. 17)

N.E. Asia (Ch. 2I)

Wildfires

\author{
California (Ch. 2)
}

\section{W. Tropical \& N.E. Pacific}

Sea Surface

Temperature

(Ch. 20)

N.W. Atlantic \& N.E. Pacific (Ch. 13)

Sea Level

Pressure

S. Australia (Ch. 32)

Sea Ice

Extent

w.

Antarctica (Ch. 33)

† Papers that did not investigate strength are not listed.

t† Papers that did not investigate likelihood are not listed.

* No influence on the likelihood of low rainfall, but human influences did result in higher temperatures and increased net incoming radiation at the surface over the region most affected by the drought.

** An increase in spring rainfall as well as extensive artificial pond drainage increased the risk of more frequent severe floods from the enhanced rainfall.

*** Evidence for human influence was found for greater risk of UK extreme rainfall during winter 20I3/14 with time scales of 10 days

***** The study of Jakarta rainfall event of 2014 found a statistically significant increase in the probability of such rains over the last II5 years, though the study did not establish a cause. 